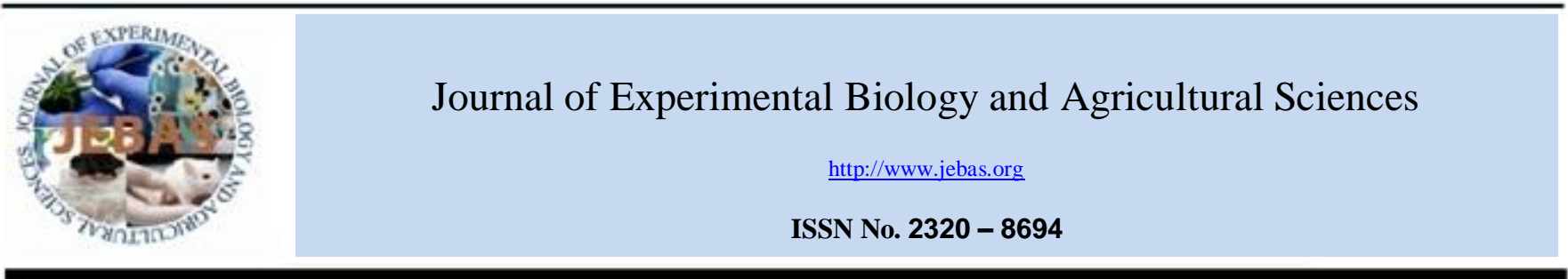

\title{
EFFECTIVE MANAGEMENT STRATEGY OF LITTLE LEAF DISEASE IN BRINJAL (Solanum melongena L.)
}

\author{
Rakesh Pandey ${ }^{1}$, A.K. Chaturvedi ${ }^{2}$ \\ ${ }^{1}$ Department of Entomology, Banda University of Agriculture \& Technology, Banda (India) \\ ${ }^{2}$ Krishi Vigyan Kendra, Bhadohi (ICAR-Indian Institute of Vegetable Research, Varanasi) (India) \\ Received - April 18, 2019; Revision - May 21, 2019; Accepted - June 08, 2019 \\ Available Online - June 10, 2019 \\ DOI: http://dx.doi.org/10.18006/2019.7(3).295.300
}

KEYWORDS
Brinjal
Little leaf disease
Phytoplasma
Integrated Pest Management
Farmers' practice
Varanasi

* Corresponding author

E-mail: pandeyent@gmail.com (Rakesh Pandey)

Peer review under responsibility of Journal of Experimental Biology and Agricultural Sciences.

Production and Hosting by Horizon Publisher India [HPI] (http://www.horizonpublisherindia.in/).

All rights reserved.

\begin{abstract}
Little leaf disease is distributed throughout the brinjal growing tracts. Farm experiments were conducted at five different locations with the technology developed by ICAR-Indian Institute of Vegetable Research, Varanasi during two consecutive years i.e., 2014-15 and 2015-16. The technologies assessed were FP (Farmers' practice): no use of chemicals to manage little leaf disease, only use chemicals viz., Profenophos, Cypermethrin etc. for the management of shoot and fruit borer; SDS: seedling treatment for 20-30 minutes with (Streptomycin Sulphate + Tetracyclin hydrochloride @ 150 ppm) + destruction of the infected plants + need based foliar application of Streptomycin Sulphate + Tetracyclin hydrochloride @ 150 ppm and Imidaclopirid @ $0.3 \mathrm{ml} / 1$ and STDS: SDS + installation of yellow sticky traps @ 15/ha after 20 days of transplanting for the management of vector i.e., leafhoppers. There were 46.27 to 57.63 per cent plants infested in FP (farmers' practice). However, 33.55 to 43.88 per cent and 18.95 to 28.58 per cent plants were infested in SDS and STDS, respectively. The highest yield was observed in STDS (39.51 to $48.10 \mathrm{t} / \mathrm{ha}$ ) followed by SDS (33.82 to $39.94 \mathrm{t} / \mathrm{ha}$ ) and FP (23.26 to 32.88 t/ha) with the highest benefit cost ratio of 4.99 to 5.86 in STDS followed by 4.51 to 5.45 in SDS and 3.86 to 3.90 in FP (farmers' practice). It is evident from the study that STDS not only increased the yield from 46.29 to 69.83 per cent but also increased net return from 57.86 to 89.35 per cent in comparison to farmers' practice.
\end{abstract}

All the article published by Journal of Experimental Biology and Agricultural Sciences is licensed under a Creative Commons Attribution-NonCommercial 4.0 International License Based on a work at www.jebas.org.

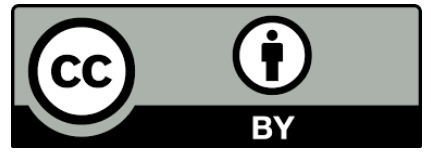




\section{Introduction}

Brinjal, Solanum melongena L. is one of the most widely grown vegetable crops of both tropics and subtropics of the world. It is being grown extensively in India, Bangladesh, Pakistan, China, Philippines, France, Italy and United States (Rathnamma \& Patil, 2017). It is one of the most important solanaceous vegetable crops in the Indian sub-continent (Srinivasan \& Huang, 2008). It contributes about $8.12 \%$ of the total vegetable production and about $8.0 \%$ of the total area under vegetables in India (Indian Horticulture Database, 2011). It is highly productive and finds its place as the poor man's vegetable (Som \& Maity, 2002). It is grown in almost all parts of India, except in higher altitudes throughout the year. Insect-pests and diseases are one of the important limiting factors in cultivation of brinjal. Little leaf disease is caused by phytoplasma and it causes significant losses (Mitra, 1993). Stunted plant growth, shortening of internodes, reduced leaf size and proliferation of shoots are the prominent symptoms of infected plants. Several biological aspects of brinjal little leaf disease was reported by Varma et al. (1969) and Mitra (1993). Plants infected with phytoplasmas exhibit symptoms suggesting a profound disturbance in the normal balance of growth regulators, leading to virescence/ phyllody i.e., development of green leaf like structures instead of flowers, sterility of flowers, proliferation of axillary buds resulting in "witches broom" symptoms, abnormal internode elongation and generalized stunting (Bertaccini, 2007). The insects of families Cicadellidae, Cixidae, Psyllidae, Delphacidae and Derbidae are responsible for transmission of phytoplasma (Weintraub \& Beanland, 2006). Bindra \& Singh (1969) reported that the Hishimonus phycitis Distant is the most common vector of this disease.

The field surveys indicated that the incidence of little leaf disease was more than 50 per cent in the study area, however, Rathnamma \& Patil, 2017 also reported up to 95 per cent incidence in brinjal growing area. Farmers usually spray insecticides viz., Profenophos, Cypermethrin, etc. once or twice at weekly intervals only to control the brinjal shoot and fruit borer (Pandey et al., 2016). There were no concerted remedies against this serious malady used by the farmers of the region. However, in India According to Alam et al. (2006), more than $95 \%$ of the farmers applied more than 40 sprays per season (in Gujrat) and 86\% sprayed their crops twice or three times a week (in Uttar Pradesh) against eggplant shoot and fruit borer. Sole reliance on chemicals for the control of $L$. orbonalis made eggplant cultivation uneconomical and also caused residual toxicity (Chandra et al., 2014). Moreover, despite serious damaging nature of little leaf disease, its control tactic by and large is limited to frequent sprays of chemical insecticides in this region. Such practices of insecticides usage is detrimental to the environment, also increases the chances of insecticide residues in the fruit Considering the principles of Integrated Pest Management (IPM), the present study was undertaken with the objective to investigate the effective management strategy by seedling treatment, destruction of infected plants, application of yellow sticky traps and need based foliar application of Streptomycin Sulphate + Tetracyclin hydrochloride and Imidaclopirid against little leaf disease under field conditions.

\section{Materials and Methods}

\subsection{Location of the study}

The study was conducted in 0.125 ha area located in Bhadohi ( $82^{0} 56^{\prime}$ east longitude and $25^{\circ} 40^{\prime}$ 'north latitude). The climate was hot and humid in summer and cold and dry in winter with an in between rainy season. The temperature in the area ranged between $5^{\circ} \mathrm{C}$ to $46^{\circ} \mathrm{C}$ and an annual rainfall of $1563 \mathrm{~mm}$ was reported (Singh et al., 2008).

\subsection{Details of technologies assessed against little leaf disease}

The different insecticides are the only control measures adopted by the farmers (FP). To find out a safe, effective, economical and sustainable strategy for the management of little leaf disease, two technologies were formulated on the basis of researches conducted at ICAR-Indian Institute of Vegetable Research, Varanasi.

FP : Farmers' practice (no use of chemicals to manage this disease, only use chemicals viz., Profenophos, Cypermethrin etc. for the management of shoot and fruit borer)

SDS : Seedling treatment for 20-30 minutes with (Streptomycin Sulphate + Tetracyclin hydrochloride @ 150 ppm) + destruction of the infected plants + need based foliar application of Streptomycin Sulphate + Tetracyclin hydrochloride@150.ppm and Imidaclopirid @ $0.3 \mathrm{ml} / 1$

STDS : SDS + installation of yellow sticky traps @ 15/ha after 20 days of transplanting for the management of vector (trap was replaced at monthly interval)

\subsection{Field trials}

Seedlings of eggplant were planted on raised beds in the first week of July, 2014 \& 2015. The improved variety New Kiran was grown in the field to test the effectiveness of different treatments. The seed bed was lightly irrigated regularly for ensuring proper 
growth and the development of the seedlings. Thirty to thirty five days old seedlings were transplanted in the second week of August, 2014 \& 2015 with a distance between row to row and plant to plant of $90 \times 90 \mathrm{~cm}$. All the agronomic practices were similar for three assessed technologies. The weeds were removed mechanically twice at 30 and 60 days after transplanting with a small spade. The infested plants were uprooted by hand when symptoms of the disease appeared in field. The application of insecticides was done by back pack sprayers.

Field trials were conducted in two successive cropping seasons (2014-15 and 2015-16) at farmers' fields. The field trials were carried out in a randomized complete block design with five replications. The unit plot size was $12 \times 7 \mathrm{~m}$ for each regime where the seedlings were transplanted.

\subsection{Data collection}

The date of pheromone traps installation (in September, 2014 \& 2015 during vegetative stage), the observations of trap catches were recorded at weekly intervals throughout the growing season (ended the last week of March, 2015 \& 2016 - full maturity of the crop). Ten plants were randomly selected from each plot and tagged for the periodical observations on yield. Starting with the first picking/harvesting (in the second week of October, 2014 \& 2015 - initiation of fruiting), fruits were weighed separately from each plot at each harvest (ended last week of March, 2015 \& 2016 - full maturity of the crop). The infested plants were marked on the basis of typical symptoms of the disease. The percent plant infestation was assessed on the basis of recording the number of plants showing disease symptoms and the total number of plants examined at each location throughout the cropping period by using the following formula:

$$
\text { Percent plant infested }=\frac{\text { Number of infested plants }}{\text { Total number of plants }} \times 100
$$

The percent plant infestation was recorded separately per plot. The plot yield of each harvesting was also recorded separately and total yield was calculated in tonnes per hectare. The economic parameters i.e., cost of cultivation, gross return, net return and benefit cost ratio were also assessed. To justify the economic viability of the appropriate management strategy against little leaf disease, the benefit: cost (B: C) ratio was calculated from the marketable yield, regarding cost of treatments incurred in the management. The market price of eggplant fruits, rate of insecticides and labor cost were undertaken as approved by the Government to compute the B: C ratio by using following formula (Baral et al., 2006):

$$
\mathrm{BC} \text { ratio }=\frac{\text { Value of yield over control (USD \$/t) }}{\text { Total cost of production (USD \$/ha) }}
$$

The cost of production comprised of costs for seed, nursery raising, field preparation, transplanting, fertilizer application, irrigation, weeding and harvesting, costs for insecticides, spraying, trap, installation of yellow sticky traps and uprooting of infested plants. The Indian rupees (INR) converted in to US dollar (USD) by conversion rate i.e., $1 \mathrm{USD}=67.75 \mathrm{INR}$.

To compute the total return, the value of fruits obtained in each treatment was calculated separately as per the market rate. The market price of eggplant was at USD \$ 103.32/t (2014-15) and at USD \$ 147.60/t (2015-16). Net return was also calculated by subtracting the total cost from total return.

\subsection{Statistical analysis}

The data collected from the experiments were subjected to analysis of variance for different treatments. Fisher's protected critical difference $(\mathrm{CD})$ test was used to indicate the difference between the treatments at the probability level of $\mathrm{p}<0.05$ following the procedure described by Gomez \& Gomez (1984).

\section{Results}

The effect of different disease management strategies on the disease infested plants was significant during both the years (Table 1). Maximum infested plants were recorded in FP (57.63\%) followed by SDS (43.88\%) and STDS (28.58\%), respectively, during 2014-15. However, there was $23.86 \%$ disease infested plants prevented over farmers' practice in SDS and $50.40 \%$ in STDS during 2014-15. Similarly, little leaf disease infested plants were maximum $(47.27 \%)$ in FP and minimum $(18.95 \%)$ in STDS with a $29.02 \%$ in SDS and $59.91 \%$ prevention in STDS during 2015-16.

A significant effect of different treatments on brinjal yield was reported doe both years. In 2014-15, maximum yield of 48.10 t/ha was recorded in STDS followed by SDS (39.94 t/ha) and FP (32.88 t/ha) with an additional gain over FP, $21.47 \%$ in SDS and $46.29 \%$ in STDS (Table 2). However, STDS was significantly superior to SDS and FP. Similar observations were recorded during 2015-16 and maximum yield was recorded in STDS (39.51 t/ha) followed by SDS (33.82 t/ha) and FP (23.26 t/ha). An additional gain of $45.40 \%$ in SDS and $69.86 \%$ in STDS were also recorded over farmers' practice. The lowest yield was recorded from FP during both years (Table 2).

Overall economic assessment for the tested management strategies showed that both years followed similar trend (Table 3). The highest total return in 2014-15 was USD \$ 4969.90/ha (STDS), followed by USD \$ 4126.91/ha (SDS) and USD \$ 3397.26/ha (FP); and in 2015-16 USD \$ 5831.97/ha, USD \$ 4992.57/ha and USD \$ 3433.91/ha for STDS, SDS and FP, 
Table 1 Percent plant infestation due to little leaf disease and percent control over farmers' practice

\begin{tabular}{|c|c|c|c|c|}
\hline \multirow[b]{2}{*}{ Technologies assessed } & \multicolumn{2}{|c|}{$2014-15$} & \multicolumn{2}{|c|}{$2015-16$} \\
\hline & Plant infestation (\%) & $\begin{array}{c}\text { Control over farmers' } \\
\text { practice }(\%)\end{array}$ & Plant infestation (\%) & $\begin{array}{c}\text { Control over farmers' } \\
\text { practice }(\%)\end{array}$ \\
\hline FP & $57.63^{\mathrm{a}}$ & - & $47.27^{\mathrm{a}}$ & - \\
\hline SDS & $43.88^{\mathrm{b}}$ & 23.86 & $33.55^{\mathrm{b}}$ & 29.02 \\
\hline STDS & $28.58^{\mathrm{c}}$ & 50.40 & $18.95^{\mathrm{c}}$ & 59.91 \\
\hline $\operatorname{LSD}(\mathrm{CD})(\mathrm{P}=0.05)$ & 3.78 & & 5.08 & \\
\hline $\mathrm{SE} \pm$ & 1.64 & & 2.20 & \\
\hline
\end{tabular}

Table 2 Total marketable yield of brinjal and percent gain over farmers' practice

\begin{tabular}{|c|c|c|c|c|}
\hline Technologies assessed & Yield (t/ha) & $\begin{array}{l}2014-15 \\
\text { Gain over farmers' practice (\%) }\end{array}$ & Yield (t/ha) & $\begin{array}{l}2015-16 \\
\text { Gain over farmers' practice (\%) }\end{array}$ \\
\hline FP & $32.88^{\mathrm{c}}$ & - & $23.26^{\mathrm{c}}$ & - \\
\hline SDS & $39.94^{\mathrm{b}}$ & 21.47 & $33.82^{\mathrm{b}}$ & 45.40 \\
\hline STDS & $48.10^{\mathrm{a}}$ & 46.29 & $39.51^{\mathrm{a}}$ & 69.86 \\
\hline $\operatorname{LSD}(\mathrm{CD})(\mathrm{P}=0.05)$ & 1.93 & & 2.17 & \\
\hline SE \pm & 0.84 & & 0.94 & \\
\hline
\end{tabular}

Table 3 Overall economic assessment of field trials

\begin{tabular}{|c|c|c|c|c|}
\hline Year & Benefit : Cost assessments & FP & SDS & STDS \\
\hline \multirow[t]{4}{*}{$2014-15$} & Cost of production (USD \$) & 879.40 & 915.27 & 994.97 \\
\hline & Total Return (USD \$) $)^{1}$ & 3397.26 & 4126.91 & 4969.90 \\
\hline & Net Return (USD \$) & 2517.86 & 3211.64 & 3974.93 \\
\hline & Benefit / Cost ratio & 3.86 & 4.51 & 4.99 \\
\hline \multirow[t]{4}{*}{ 2015-16 } & Cost of production (USD \$) & 879.40 & 915.27 & 994.97 \\
\hline & Total Return (USD \$) $)^{2}$ & 3433.91 & 4992.57 & 5831.97 \\
\hline & Net Return (USD \$) & 2554.51 & 4077.30 & 4837.00 \\
\hline & Benefit / Cost ratio & 3.90 & 5.45 & 5.86 \\
\hline
\end{tabular}

${ }^{1}$ Market price of eggplant at USD \$ 103.32/t during 2014-15.

${ }^{2}$ Market price of eggplant at USD \$ 147.60/t during 2015-16.

respectively. The benefit: cost ratio was observed to be higher in STDS (4.99) followed by SDS (4.51) and FP (3.86) during 201415 and STDS (5.86), SDS (5.45) and FP (3.90) during 2015-16. The highest additional income over FP (the difference of net return between STDS and FP) was USD \$ 1457.06/ha and USD \$ 2208.69/ha during 2014-15 and 2015-16, respectively.

\section{Discussion \& Conclusion}

The severity of the little leaf disease, shortening of internodes, excessive branching giving witches' broom appearance on brinjal plants is growing rapidly in brinjal growing tracts. Azadvar \& Baranwal (2012) observed only 2-4 per cent in New Delhi. Little leaf disease symptoms were observed in approximately 20 per cent of the brinjal (S. melongena) in a survey in Bihar (Kumar et al., 2012). The diseased plants exhibited proliferation of branches with shortened internodes and reduced-size leaves which gave rise to the little leaf appearance (Raj et al., 2008). It revealed that there was 47.27 to 57.63 percent plants were infested with little leaf disease. However, Rathnamma \& Patil (2017) reported up to 95 per cent incidence of the little leaf disease in brinjal growing areas of Karnataka. Different studies over the years showed that there is 
an increasing trend of spreading little leaf disease in brinjal growing tracts.

Due to catch the better market price, the farmers transplant the brinjal early that is also one of the important pre-disposing factors of this disease. Therefore, different disease management strategies were evaluated so that farmers fetch a good income from cultivation of brinjal. ICAR-Indian Institute of Vegetable Research, Varanasi has recommended the use of tetracycline @ 100 ppm (Pandey et al., 2003) to manage the little leaf disease. Bindra et al. (1972) also reported that plants treated with $500 \mathrm{ppm}$ of the tetracycline resumed normal growth with respect of leaf size and length of internodes 30 to 37 days after the last spray. In other treatments i.e., 100, $250 \mathrm{ppm}$ recovery was also observed but it was not pronounced. However, disease symptoms started reappearing 16 to 63 days after the last spray i.e. 14 sprays of the tetracycline suppressed the symptoms only for 20 to 30 days. The disappearance of symptoms after antibiotic (i.e., tetracycline) treatment provided additional evidence to support the diagnosis (Lee \& Davis, 1992). A minimum incubation period of 15 days was observed to be essential in the vector for successful transmission and optimum incubation period of the mycoplasma in the host plant was recorded to be 35 days. In nature, the brinjal plants are likely to be infected in the nursery or after transplanting, a properly devised method for infiltrating the plants with tetracyclines before transplanting would eliminate the chances of carrying the little leaf disease from nursery to field (Varma et al., 1969).

Brinjal little leaf disease is transmitted by insects (leaf hopper) such as Hisimonus phycitis which is common on brinjal crop (Singh et al., 2014; EFSA Panel on Plant Health, 2017). Further, Srinivasan \& Chelliah (1977) reported that transmission of little leaf mycoplasma of $S$. melongena by $H$. phycitis revealed that the minimum acquisition and inoculation feeding period was one hour each while the optimum was 24 and 48 hours, respectively. For the management of leafhopper, imidacloprid has been used. Mhaske \& Mote (2005) found that imidacloprid (18 g/ ha), thiamethoxam (25 $\mathrm{g} / \mathrm{ha}$ ) were effective against jassids (Amrasca bigutulla bigutulla) up to 14 days after spray. Foliar application of imidacloprid caused immediate and long-lasting reductions in control potato leafhopper, Empoasca fabae (Harris) (van Timmeren et al., 2011). Yellow sticky trap is also an added advantage to manage the leaf hoppers. When the crop is in vegetative stage there is normally no sign of incidence of little leaf disease observed. However, in reproductive phase when the canopy is in full swing the multiplication of leaf hoppers takes place rapidly consequently, the incidence of the disease also aggravates. During multiplication of leaf hoppers, the yellow sticky trap acts as barrier to move away between plants and thus reducing the population of leaf hoppers and minimizing the little leaf disease incidence.
There is scanty literature pertaining to the study, however, the available literature is in the line of confirmation of the findings. Sole reliance on chemical insecticides was found to be highly uneconomical (Baral et al., 2006; Srinivasan, 2008) as less return was obtained against per rupee invested. This was mainly due to the high cost of insecticide and the labor charges engaged in their sprayings. It is evident from the study that the seedling treatment for 20-30 minutes with (Streptomycin Sulphate + Tetracyclin hydrochloride @ 150 ppm) + installation of yellow sticky traps @ 15/ha after 20 days of transplanting + destruction of the infected plants + need based foliar application of Streptomycin Sulphate + Tetracyclin hydrochloride @ 150 ppm and Imidaclopirid @ 0.3 $\mathrm{ml} / \mathrm{l}$ for the management of vector not only increased the yield from 46.29 to 69.83 per cent but also increased net return from 57.86 to 89.35 per cent in comparison to farmers' practice.

\section{Acknowledgements}

The authors' gratefully acknowledge the financial support and encouragement from Directors, ICAR-Indian Institute of Vegetable Research, Varanasi and ICAR-Zonal Project Directorate Zone - IV, Kanpur.

\section{Conflict of Interest}

Authors would hereby like to declare that there is no conflict of interests that could possibly arise.

\section{References}

Alam SN, Hossain MI, Rouf FMA, Jhala RC, Patel MG, Nath LK, Sengupta A, Baral K, Shylesha AN, Satpathy S, Shivalingaswamy TM, Cork A, Talekar NS (2006) Control of eggplant fruit and shoot borer in South Asia. Technical Bulletin 36, AVRDC - The World Vegetable Center, Shanhua, Taiwan.

Azadvar M, Baranwal VK (2012) Multilocus sequence analysis of phytoplasma associated with brinjal little leaf disease and its detection in Hishimonus phycitis in India. Phytopathogenic Mollicutes 2:15-21.

Baral K, Roy BC, Rahim KMB, Chatterjee H, Mondal P, Mondal D, Ghosh D, Talekar NS (2006) Socio-economic parameters of pesticide use and assessment of impact of an IPM strategy for the control of eggplant fruit and shoot borer in West Bengal, India. Technical Bulletin No. 37. AVRDC publication number 06-673. AVRDC-The World Vegetable Center, Shanhua, Taiwan, Pp. 36.

Bertaccini A (2007) Phytoplasmas: diversity, taxonomy, and epidemiology. Frontiers in Bioscience 12: 673-689.

Bindra OS, Singh B (1969) Biology and bionomics of Hishimonus phycitis (Distant), a jassid vector of little leaf disease of brinjal 
(Solanum melongena L.). Indian Journal of Agricultural Sciences 39: 912-919.

Bindra OS, Sohi SA, Khatri HL, Deol SG (1972) Effect of achromycin (Tetracycline hydrochloride) on brinjal little leaf pathogen. Current Science 41: 819-820.

Chandra S, Mahindrakar AN, Fugare MK, Shinde LP (2014) Studies on persistence pattern of pesticides on brinjal. International Journal of Current Research in Chemistry and Pharmaceutical Sciences 1: 88-91.

Gomez KA, Gomez AA (1984) Statistical Procedures for Agricultural Research, second ed. John Wiley and Sons, New York, NY, USA.

Indian Horticulture Database (2011) National Horticulture Board, Ministry of Agriculture, Govt. of India, Pp. 278.

EFSA Panel on Plant Health (PLH), Jeger M, Bragard C, Caffier D, Candresse T, Chatzivassiliou E, Dehnen-Schmutz K, Gilioli G, Gregoire JC, Anton J, Miret J, Navarro MN, Niere B, Parnell S, Potting R, Rafoss T, Rossi V, Urek G, Bruggen AV, van der Werf W, West J, Winter S, Gardi C, Aukhojee M, Bergeretti F, MacLeod A (2017) Pest categorisation of Hishimonus phycitis. EFSA Journal. 15. 10.2903/j.efsa.2017.5037.

Kumar J, Gunapati S, Singh SP, Lalit A, Sharma NC, Tuli R (2012) First report of a 'Candidatus Phytoplasma asteris'(16Srl group) associated with little leaf disease of Solanum melongena (brinjal) in India. New Disease Reports 26: 21.

Lee IM, Davis RE (1992) Mycoplasmas which Infect Insects and Plants. In: Maniloff J, McElmansey RN, Finch LR, Baseman JB (Eds), Mycoplasmas: Molecular Biology and Pathogenesis, American Society for Microbiology, Washington DC, pp. 609.

Mhaske BM, Mote UN (2005) Studies on evaluation of new insecticides against brinjal pest complex. Journal of Maharashtra Agricultural Universities 30: 303-306.

Mitra DK (1993) Little leaf, a serious disease of eggplant (Solanum melongena). In: Management of plant diseases caused by fastidious prokaryotes, edited by Raychaudhuri SP, Teakle DS Associated Publishing Co. New Delhi, India Pp. 73-78.

Pandey KK, Pandey PK, Chandra S (2003) Sabjiyo me ekikrit nashijeev prabandhan, ICAR-Indian Institute of Vegetable Research, Varanasi, Pp. 9-10.

Pandey R, Chaturvedi AK, Chaudhary RP (2016) Effectiveness of IPM strategies against eggplant shoot and fruit borer Leucinodes orbonalis (Lepidoptera: Crambidae). Journal of Crop Protection 5: 553-563. doi: 10.18869/modares.jcp.5.4.553

Raj SK, Snehi SK, Kumar S, Khan MS (2008) First finding of 'Candidatus Phytoplasma trifolii' (16SrVI group) associated with little leaf disease of Datura inoxia in India. New Disease Reports 18: 44.

Rathnamma, Patil MS (2017) Survey for Little Leaf of Brinjal Disease (Candidatus Phytoplasmatrifolii) Incidence in Northern Karnataka. International Journal of Current Microbiology \& Applied Sciences 6(11): 1248-1253. doi: https://doi.org/10.20546/ijcmas.2017.611.148

Singh AK, Singh L, Singh A, Singh RK (2008) District specific technological interventions for eastern region. In: Inventory of Agricultural Technologies for Uttar Pradesh, Zonal Coordination Unit, Zone IV, Indian Council of Agricultural Research, Pp. 93.

Singh BK, Singh S, Singh BK, Yadav SM (2014) Some Important Plant Pathogenic Disease of Brinjal (Solanum melongena L.) and their Management. Plant Pathology Journal, 13: 208213.doi 10.3923/ppj.2014.208.213.

Som MG, Maity TK (1986). Brinjal. In: Bose TK, Som MG (Eds.), Vegetable Crops in India, $3^{\text {rd }}$ revised edition, Naya Prakash, Calcutta, pp. 293-335.

Srinivasan K, Chelliah S (1977) Transmission studies on little leaf mycoplasma of brinjal. Madras Agricultural Journal 64:94-98.

Srinivasan R (2008). Integrated Pest Management for eggplant fruit and shoot borer (Leucinodes orbonalis) in south and southeast Asia: Past, Present and Future. Journal of Biopesticides 1: 105-112.

Srinivasan R, Huang CC (2008) Effect of simulated borer infested shoot pruning on yield parameters of eggplants. Journal of Asia Pacific Entomology 12: 41-43. DOI: https://doi.org/10.1016/j.aspen.2008.10.001.

Van Timmeren S, John CW, VanderVoort C, Isaacs R (2011) Comparison of foliar and soil formulations of neonicotinoid insecticides for control of potato leaf hopper, Empoasca fabae (Homoptera: Cicadellidae), in wine grapes. Pest Management Science 67: 56-567.

Varma A, Raychaudhuri SP, Chenulu VV, Singh S, Ghosh SK, Prakash N (1969) Yellows Type of Diseases in India: Eggplant little leaf. Division of Mycology and Plant Pathology, Indian Agricultural Research Institute, New Delhi.

Weintraub PG, Beanland L (2006) Insect vectors of phytoplasmas. Annual Review of Entomology 51: 91-111. 